\title{
København - Cairo tur/retur: Om transnational politisk aktivisme under karikaturkrisen og det 'arabiske forår'
}

\author{
Af Lasse Lindekilde
}

\begin{abstract}
Recent scholarly work on political protest has often highlighted the potential of new social media in gathering transnational support and driving political reforms, not least in authoritarian regimes. This idea seems to have won even more credence after the 'online revolutions' of the 'Arab spring' in early 2011. However, as this article demonstrates, attempts at creating transnational exposure of national political issues through various forms of transnational political activism may also, under certain circumstances, be linked to significant costs. The article delivers an empirical analysis of the effects of Danish Muslims' transnational activities during the Muhammad cartoons controversy in 2005/06 on subsequent Muslim claims-making. The article argues that the envisioned 'boomerang effect' of the transnational activities - the attempt to put pressure on Danish authorities by contacting political and religious authorities in the Middle East - backfired on Danish Muslims. The transnational move was successfully 'securitized' by elements of the media and the political elite, inviting soft forms of repression against especially the Muslim actors involved in the delegations of primarily religious authorities that travelled to Egypt, Lebanon, and Syria in December 2005. These actors were forced into a more defensive mode of claims-making soon after their return to Denmark through processes of name-calling and stigmatization. Building on this case study, the article concludes by suggesting some theoretical modifications/specifications of the boomerang model of transnational activism.
\end{abstract}

Protesterne mod Jyllands-Postens publicering af tolv karikaturer af profeten Muhammed i september 2005 blev i Danmark ledet af en ad hoc-koalition af muslimske organisationer, som blev grundlagt i dagene efter offentliggørelsen af karikaturerne, og som samlede en bred vifte af nationale og lokale organisationer $^{1}$

\footnotetext{
${ }^{1}$ Forfatteren skylder en stor tak til en anonym referee for konstruktive kommentarer og forslag til forbedringer $\mathrm{i}$ forhold til en tidligere version af denne artikel.
} 
De fleste var domineret af arabiske muslimer, men der deltog også repræsentanter fra de numerisk store somaliske og tyrkiske organisationer. Den ledende gruppe i koalitionen var Det Islamisk Trossamfund, som var den dominerende muslimske organisation i Danmark forud for karikaturkrisen. Som reaktion på den manglende succes med at tilvejebringe en form for undskyldning i Danmark i månederne efter offentliggørelsen bestemte denne ad hoc-koalition sig i løbet af december 2005 for at internationalisere konflikten. Deres transnationale aktiviteter, som markerede starten på karikaturkrisens anden fase ${ }^{1}$, udspillede sig på mindst to niveauer: en delegation blev sendt til Mellemøsten for at mødes med politiske eliter og religiøse autoriteter i et forsøg på at sikre ekstern støtte til de danske muslimers krav; og sociale medier og globale tv-stationer som al-Jazeera og al-Arabiya blev inddraget for at sprede kendskabet til karikaturerne. Flere af disse aktiviteter, særligt de såkaldte 'imam-delegationer' til Mellemøsten, som blev gennemført i december 2005, blev modtaget med skepsis i den danske befolkning: hvad var de bagvedliggende motivationer for og interesser i at gøre karikaturerne til et internationalt anliggende? Smed nogle danske muslimer bevidst brænde på bålet i udlandet? Fremlagde disse personer et fair og præcist billede af situationen i Danmark?

Kendsgerningen er, at indholdet af den danske karikaturdebat begyndte at forandre sig i januar $2006 \mathrm{i}$ takt med, at konflikten eskalerede i udlandet med de første massedemonstrationer mod karikaturerne samt flagafbrændinger og forbrugerboykot af danske produkter. I den første uge af februar 2006, begyndelsen på krisens tredje fase, indtraf der en række voldelige episoder med stormløb og ildspåsættelse ved de danske ambassader i Damaskus og Teheran og det danske konsulat i Beirut, hvilket markerede krisens højdepunkt. Begyndelsen på krisens nedtrapning og demobiliseringen af folkelige protester, den fjerde og sidste fase, kan iagttages fra slutningen af februar 2006 og fremefter. Det er en yderligere kendsgerning, at de danske muslimer, som deltog i imam-delegationerne, blev tvunget til at gå i forsvarsposition under de sidste to faser af krisen. Med udgangspunkt i disse observationer undersøger denne artikel 1) danske muslimers beslutning om at deltage i transnationale protester, 2) måden hvorpå disse aktiviteter gav bagslag for de involverede danske muslimer, 3) de teoretiske implikationer af denne form for dynamisk samspil mellem transnational aktivisme og forskellige typer af statsrepression, og 4) begivenhedernes mulige langsigtede konsekvenser for både danske muslimer og den danske politiske elite. Artiklens formål er, gennem et casestudie af danske muslimers protester under karikaturkrisen at belyse hvordan og under hvilke omstændigheder, 
transnational politisk aktivisme fungerer/ikke fungerer efter hensigten. Indsigter fra dette casestudie vil løbende blive sammenholdt med den transnationale aktivisme via nye sociale medier, som har spillet en central rolle for udviklingen af det 'arabiske forår' i Nordafrika og Mellemøsten siden februar 2011. Hvor transnational politisk aktivisme banede vejen for politiske forandringer i fx Tunesien og Egypten, viste danske muslimers brug af transnational aktivisme under karikaturkrisen, hvordan denne strategi kan slå fejl og give bagslag. Artiklen argumenterer således for behovet for at nuancere vores forståelse af transnational aktivismes potentiale i realiseringen af politiske krav og griber tilbage til karikaturkrisens transnationale dynamikker for at perspektivere 'succeshistorien' om sociale medier og transnational eksponering under det 'arabiske forår'.

\section{Metodiske overvejelser}

Artiklen bygger metodisk på en politisk 'claims analysis'-tilgang, som integrerer elementer af 'protestevent analysis', diskursanalyse og frame-analyse. Et 'claim' eller krav er her defineret bredt som tilkendegivelse af et politisk synspunkt i den offentlige debat via sproglige eller fysiske manifestationer (se Koopmans \& Statham 1999a). Der trækkes på en empirisk database over fremsatte krav under karikaturkrisen. Databasen indeholder detaljerede kodninger af alle avisartikler vedrørende krisen, som blev publiceret i Berlingske Tidende fra karikaturerne blev publiceret den 30. september 2005 til krisens demobilisering ved udgangen af februar 2006. Valget af Berlingske Tidende er baseret på et pilotstudie, som viste, at avisen indtog en midterposition blandt de tre største danske dagblade med hensyn til at placere ansvaret for konfliktens eskalering hos den danske regering og/eller danske muslimer ${ }^{2}$. Beslutningen om alene at anvende en enkelt avis kan retfærdiggøres gennem eksisterende forskning i aviser som datakilde for kortlægning af protestcyklusser, som viser, at under intens offentlig debat af national karakter dækker alle større aviser samme begivenheder og synspunkter (se fx Strawn 2008). Dette ser ud til at være tilfældet for dækningen af karikaturkrisen i Danmark. Det har desuden, ud fra et pragmatisk synspunkt, været nødvendigt at begrænse kodningen til en enkelt avis som følge af den omfattende dækning af krisen i den danske presse. Der blev alene i Berlingske Tidende publiceret 893 artikler om krisen i undersøgelsesperioden. 
En ofte fremført kritik af denne form for 'claims analysis'-tilgang er, at fokus på avisdata reproducerer den selektionsbias, som avisartikler nødvendigvis indeholder, idet dækningen bygger på bestemte nyhedskriterier. Nogle aktører og typer af kravfremsættelse (eksempelvis mindre højlydte eller mindre synlige politiske interesser) vil være underrepræsenterede i avisdata. Jeg forsøger at kompensere for dette ved at inkludere andre typer af datamateriale i mit empiriske datasæt (herunder interne nyhedsbreve, pamfletter, organisatoriske dokumenter, fredagsbønner samt noter fra interne debatter eller møder), som indeholder krav fremsat af muslimske aktører, der var aktive i den offentlige debat om karikaturerne. En yderligere kritik af 'claims analysis'-tilgangen er, at kompleksiteten af den offentlige kravfremsættelse oversimplificeres ved, at der fokuseres på kvantificeringen af hvem, der sagde hvad, hvor og hvorfor. For at imødekomme denne kritik støttes min analyse derfor af interviews med repræsentanter fra de muslimske organisationer, som var aktive i debatten. I den følgende analyse vil den konstruerede database og interviews blive anvendt til at spore konsekvenserne af danske muslimers transnationale aktivisme på 1) den generelle danske debat om karikaturerne, 2) indholdet af muslimske krav i Danmark og 3) mobiliseringen/demobiliseringen blandt forskellige muslimske aktører i Danmark. Denne analyse vil løbende blive sammenholdt med indsigter, som bygger på sekundære kilder om den transnationale aktivisme blandt unge aktivister under det 'arabiske forår'. Artiklen vil dog først præsentere nogle teoretiske overvejelser om forholdet mellem forskellige former for statsrepression og transnational aktivisme samt muligheden for, at enten repression eller aktivisme giver bagslag.

\section{Repression, transnational aktivisme og bagslag}

For at forstå hvorfor danske muslimer valgte den transnationale aktivisme og de konsekvenser denne beslutning havde for den efterfølgende muslimske kravfremsættelse i Danmark, kan der trækkes på viden fra den eksisterende litteratur om forholdet mellem statslig repression og mobiliseringen af kritiske røster/krav i et samfund (for et overblik se Davenport, Johnston \& Mueller 2005). I denne litteratur bliver graden og formen af statslig repression ofte anset for at være afgørende elementer i de politiske mulighedsstrukturer, som systemkritikere møder i en given kontekst, og anses for at medforme typen og intensiteten af kravfremsættelse i opposition til statslige autoriteter. Repression har ifølge litteraturen tre konsekvenser for mobilisering. For det første har repressive politiske tiltag, såsom 
politiopbud ved protester, overvågning, censur, masseanholdelser og 'stop and search'-zoner, vist sig at øge omkostningerne ved kravfremsættelse, hvilket har ført til en demobilisering af oppositionen (se fx White 1993). Det er tydeligvis hensigten med sådanne politiske tiltag og har eksempelvis traditionelt været med til at holde folkelige protester for reformer i ave i store dele af Mellemøsten. For det andet har forskningen i andre tilfælde vist, hvordan repression ikke altid får demonstranter til at opgive deres krav, men i stedet forandrer protestens udtryk. I autoritære regimer, som eksempelvis Chile under Pinochet eller Spanien under Franco, som var kendetegnet ved hård statslig repression, viste modstanden mod regimet sig at blive mere personlig og privat og derfor udtrykt gennem mere subtile ytringsformer og arenaer frem for kollektive gadeprotester (Johnston 2005). De senere år har sociale medier vist sig som et nyt slagkraftigt værktøj for politisk protest i autoritære regimer, idet disse mediers kommunikation kun vanskeligt lader sig kontrollere og effektivt kan forene ellers adskilte samfundsgrupper (Shirky 2011). Senest har de nye sociale medier været en væsentlig kilde til politisk mobilisering og koordinering under det 'arabiske forår', hvor online-mobilisering i lande som Egypten, Jordan, Bahrain, og Syrien understøttede og flød sammen med politiske protester offline (Lunch 2011: 301). På samme måde hævder en del af litteraturen, at en national repressiv politik kan presse demonstranter til at udvide lokale, nationale eller regionale uenigheder til en transnational arena for at skaffe opbakning til deres krav (Olesen 2005; della Porta \& Tarrow 2004; Guiraudon 2001). Det er netop her, at de nye sociale medier med deres globale karakter og evne til at sprede informationer på tværs af grænser, har kunnet spille en så vigtig rolle for fx det 'arabiske forår'. Via blogs, Facebook, Youtube og Twitter har hele verden kunnet følge med helt tæt på i protesterne på eksempelvis Tahrirpladsen i Cairo.

En delmængde af denne litteratur om sammenspillet mellem repression, mobilisering og transnationalaktivisme har fokuseret på transnational aktivisme blandt immigranter. Her er det ofte blevet understreget, hvordan immigranter er forblevet socialt, kulturelt, økonomisk og politisk involveret i deres hjemland med afgørende positiv betydning (investeringer, demokratisk know-how, handel osv.) herfor (Basch, Schiller \& Blanc 1994; Danese 1998; Portes 1997; Van Hear 1998; Guarnizo \& Portes 2003). Nogle forskere peger på, at graden af transnationale aktiviteter blandt immigranter afhænger af mulighederne for integration og politisk deltagelse i bosættelseslandet, hvor 
bedre muligheder for deltagelse i bosættelseslandet mindsker sandsynligheden for, at immigranter vil deltage i transnationale aktiviteter rettet mod oprindelseslandet (Koopmans \& Statham 1999b, 2001).

Med afsæt i et lignende framework om 'lukkede’ og ‘åbne' mulighedsstrukturer, har Keck og Sikkink fremsat deres 'boomerang-model' for transnational aktivisme (Keck \& Sikkink 1998). Ideen om boomerang-effekten blev oprindeligt udviklet for at kunne forklare forbedringer af menneskerettigheder i autoritære regimer. Argumentet er, at på grund af et repressivt regime i hjemlandet, appellerer nationale menneskerettigheds-NGO'er til udenlandske regeringer, internationale institutioner eller NGO'er i andre lande for at lægge pres på det repressive regime. Eksterne allierede kan eksempelvis forsøge at opnå politisk forandring gennem trusler om materielle eller symbolske repressalier, hvis der ikke sker indsigelser. De unge som var involveret i det 'arabiske forår', benyttede i høj grad blogs, Facebook, Youtube og Twitter i overensstemmelse med denne model. Det kan være svært at vurdere den egentlige effekt af denne form for transnational online-aktivisme, men den har utvivlsomt været med til at sprede information om opstanden og skabe en atmosfære af forandring i det internationale samfund. Faktum er, at i takt med, at de politiske protester tog til i Nordafrika, begyndte det internationale samfund (ganske vist noget tøvende) at lægge pres på de etablerede regimer for politiske forandringer.

For det tredje har repression vist sig at have ikke-tilsigtede, negative konsekvenser i form af øget mobilisering af dissens (Lichbach 1987). Når befolkningen eller dissidenternes allierede opfatter repression som uretfærdig eller ude af proportioner, kan den blive en mulighed snarere end en omkostning for mobiliseringen. Denne mekanisme er blevet refereret til som 'backfire' (Hess \& Martin 2006). 'Backfire' eller bagslagsmekanismer er hovedsageligt blevet knyttet til handlinger, som involverer hård repression såsom politi/militærbrutalitet. Det 'arabiske forår' har vist flere eksempler på dette. For eksempel syntes militærets brutale slåen ned på demonstranter i Syrien ikke at have kuet modstanden, men snarere at have styrket den. På samme måde med det Egyptiske regimes forsøg på at lukke ned for mobiltelefoni og internet i januar 2011, hvilket blot fik demonstranterne til at stimle fysisk sammen på Tahrir-pladsen. Men bløde former for repression, såsom hån mod bestemte personer, stigmatisering af grupper samt offentlige udtalelser, som tager afstand fra bestemte aktører, kan også give bagslag (se specielt Ferree 2005). Eksempelvis har forsøg på at delegitimere eller lukke munden 
på muslimer i Vesteuropa, der kategoriseres som 'radikale' i nogle tilfælde vist sig at virke imod hensigten, fordi disse grupper er blevet yderligere marginaliserede fra majoriteten og herigennem gjort mere attraktive for muslimer, som føler sig fremmedgjorte i samfundet (Schiffauer 2008; Lindekilde 2012).

Det er vigtigt at bemærke, at forholdet mellem repression og mobilisering er dynamisk. Med andre ord influerer mobilisering og modstandsreaktioner også på statslig repression. Her er litteraturen i højere grad enslydende: Øget mobilisering og udfordring af autoriteter vil få autoriteter til at øge repressionen. For eksempel fik massedemonstrationerne og de politiske protester i Libyen Gaddafi-regimet til at sætte ind med fly mod civile demonstranter. Medierne og den offentlige opinion spiller en afgørende rolle for at signalere til stater, hvorvidt, og i hvilket omfang, repression af bestemte former for dissens bliver tilskyndet. Gennem framing af handlinger/krav som legitime eller illegitime skaber medierne og den offentlige opinion 'diskursive muligheder', som enten åbner op eller blokerer for statslig repression (Koopmans 2005).

Hvis vi ser på den transnationale aktivisme blandt danske muslimer under karikaturkrisen i lyset af den eksisterende litteratur om det dynamiske forhold mellem repression og mobilisering, fremgår to ting. For det første følger disse aktiviteter, særligt imam-delegationerne, den oprindelige logik bag ‘boomerang-modellen' for transnational aktivisme. På grund af de manglende politiske reaktioner på protester i Danmark var tanken at løfte karikatursagen ud af en dansk kontekst - at foretage et 'scale shift' - og herved lægge pres på den danske regering udefra (Tarrow \& Tilly 2006: 217). For det andet synes den transnationale dynamik, som blev sat i gang at virke modsat af de involverede danske muslimers håb og forventninger. De transnationale aktiviteter fik, som følge af den måde de blev 'framet' og opfattet på i den danske offentlighed, meget negative kortsigtede konsekvenser for den efterfølgende realisering af muslimske krav i Danmark. Resten af denne artikel analyserer disse udviklinger mere detaljeret. 


\section{Danske Muslimers beslutning om transnational aktivisme}

I løbet af december 2005 og januar 2006 valgte ad hoc-koalitionen af danske muslimske organisationer, som nævnt, at brede sagen om karikaturerne ud til en transnational arena med henblik på at finde eksterne allierede på grund af de 'lukkede' politiske mulighedsstrukturer i en dansk politisk kontekst. Gennem demonstrationer, brevskrivning, diplomatiske kontakter, underskriftsindsamlinger og retssager forsøgte koalitionen først at rejse sine krav gennem det danske politiske system og retsvæsen. Disse handlinger viste sig at være frugtesløse. Derfor bestemte koalitionen sig i december 2005 for at 'internationalisere' konflikten. Som talsmanden for koalitionen, Ahmed Akkari, udtrykte det:

Efter to måneders forsøg på at forklare vores synspunkter i Danmark, uden at nogen lyttede eller reagerede på dem, så vi ingen anden udveje end at kontakte indflydelsesrige personer i udlandet og håbede, at de kunne gøre vores synspunkter hørte (Islamisk Trossamfund, 2. marts 2006).

Med andre ord var transnationaliseringen af sagen en reaktion på den 'bløde repression', som den danske regering udøvede gennem sin tavshed og afslag på at mødes med koalitionens repræsentanter.

Mindst tre faktorer gjorde den transnationale arena 'åben' for et sådant træk. For det første gjorde genstanden for danske muslimers indsigelser - hånen af Profeten Muhammed - muslimske samfund i udlandet modtagelige over for danske muslimers krav om en undskyldning. For mange muslimer var angrebet på Muhammed et angreb på alle muslimer. Offentliggørelsen af karikaturerne indebar således et vist transnationalt konfliktpotentiale. For det andet var Muhammedkarikaturerne en velkommen mulighed for flere muslimske regimer i Mellemøsten og andre steder til at vise, at de stod vagt om respekten for islam for herigennem at opbløde kritikken fra islamisk opposition internt. Her var en sag, som i høj grad var værdiladet og næsten omkostningsfri som diplomatisk konflikt. For det tredje var danske muslimske aktører i besiddelse af de nødvendige ressourcer til at gøre det transnationale skridt muligt. Vigtigst af alt havde de værdifulde transnationale forbindelser til magtfulde religiøse autoriteter i lande som Egypten, Libanon og Syrien - 'hjemlande' for flere af aktørerne i imam-delegationerne. Eksempelvis mødtes delegationerne med generalsekretæren i Den Arabiske Liga Amr Moussa, 
stormuftien fra al-Azhar Universitet, Sheikh Muhammad Sayyid Tantawi og den indflydelsesrige sunni-prædikant Yusuf al-Qaradawi.

Imam-delegationerne var de mest synlige og de mest afgørende blandt danske muslimers transnationale aktiviteter under krisen. Der var dog også andre. Danske muslimer gjorde således også brug af traditionelle og sociale medier til at udbrede krav i forbindelse med karikaturerne transnationalt (se også Olesen 2007). Med sociale medier menes her e-mail, sms-kædebeskeder, blogs og chat-fora, hvilket de danske muslimer i vidt omfang gjorde brug af og udnyttede den lethed og hurtighed, hvormed sådanne IT-baserede kommunikationsværktøjer kan udbrede synspunkter. Dog er 'ukontrollerbarheden' af sådanne medier og letheden forbundet med at sprede budskaber også blandt disse mediers ulemper. Rygter, misinformationer og misforståelser har en tendens til at florere og få deres eget liv. Karikaturkrisen producerede adskillelige af sådanne eksempler. Blandt disse var rygtet om koranafbrændinger i Danmark, som spredtes til Mellemøsten gennem en sms-kædebesked den 4. februar 2006 og angiveligt ansporede den vrede folkemængde foran den danske ambassade i Damaskus den samme eftermiddag. Ligeledes indeholdt en boykotliste over 'danske' produkter/virksomheder, som florerede i muslimske chat-fora og blogs, flere virksomheder, som ikke er, og aldrig har været, danske. I et forsøg på at modvirke sådanne misinformationer, loggede medlemmer af den multietniske, danske organisation Muslimer i Dialog sig på disse chat-foras for at overvåge diskussionerne af Muhammedkarikaturerne og korrigere den udbredte misinformation om situationen i Danmark. En repræsentant fra organisationen forklarede initiativet på følgende måde:

Det vigtige er at få yderligere eskaleringer stoppet...[...]...Der er mange misforståelser omkring sagen, der har skabt denne uheldige situation, vi står i. Derfor føler vi, at det er oplagt at bruge samme medie til at fortælle, hvad faktum er, hvordan vi muslimer i Danmark føler, og at dialog er bedre end konfrontation. Vi håber, at vores besked til andre muslimer i verden vil sprede sig som ringe i vandet på samme måde som misforståelserne gjorde (Muslimer i Dialog, 9. februar 2006),

For så vidt angår traditionelle medier benyttede muslimske organisationer og enkeltindivider i Danmark sig af kontakter til journalister ved tv og aviser i 'hjemlandet'. Opmærksomhed omkring 
karikaturerne på globale stationer som al-Jazeera og al-Arabiya, gjorde det muligt for repræsentanter for danske muslimer at tale til et stort transnationalt samfund af muslimer (og ikke-muslimer) i udlandet.

Danske muslimer var, som antydet, involveret i kravfremsættelse i forskellige arenaer samtidig - for eksempel lokale moskeer, den danske offentlighed og udenlandske offentligheder. I mindst ét tilfælde skabte denne strategi dog problemer for de involverede muslimske aktører, da det kom frem, at der var uoverensstemmelse i kravfremsættelsen på tværs af arenaerne. I slutningen af januar 2006 fremførte Ahmed Abu Laban, som var imam og talsmand for Det Islamisk Trossamfund, tilsyneladende modstridende udtalelser i den danske og den arabiske presse. Han støttede boykottet af danske virksomheder i et interview med al-Jazeera, men udtrykte sympati med de danske virksomheder, som var ramt af boykottet, i et interview med en dansk avis. Denne episode og, mere generelt, opfattelsen af, at imam-delegationerne havde eskalerende konsekvenser for krisen, gjorde danske muslimers transnationale aktiviteter centrale i den efterfølgende debat, omend på en negativ måde. Udtryk som 'tvetunget tale', 'skjulte dagsordener' og 'janus-agtige' imamer var typiske beskrivelser af muslimers kravfremsættelse i den offentlige debat. I det følgende undersøger jeg, hvordan opfattelsen af danske muslimers transnationale aktiviteter åbnede op for yderligere blød repression fra de danske myndigheder mod de involverede aktører og hvordan denne repression indvirkede på den efterfølgende muslimske mobilisering og kravfremsættelse.

\section{Konsekvenserne af muslimsk transnational aktivisme for efterfølgende kravfremsattelse} I januar 2006 (krisens anden fase) sås der tegn på, at den transnationale dialektik mellem begivenhederne i Danmark og reaktionerne/begivenhederne i udlandet ville falde ud til de danske muslimers fordel. Med andre ord så det ud til, at 'transnationaliseringen' af krisen ville få positive konsekvenser for anerkendelsen af muslimske krav i Danmark. Den danske regerings indifferente indstilling til de muslimske ambassadører i Danmark i den første fase af krisen førte til stigende kritik, ikke alene fra udenlandske muslimske aktører, særligt Egypten og Den Islamiske KonferenceOrganization (OIC), men også fra en række ikke-muslimske aktører, heriblandt Europæiske ministre samt repræsentanter fra EU og FN. Den danske regering og Jyllands-Posten var således under alvorligt 
internationalt pres for at løse konflikten. Karakteren af den transnationale dialektik ændrede sig dog med den hurtige og voldelige eskalering af konflikten i udlandet i begyndelsen af februar 2006. Danske muslimer, som havde hjulpet transnationaliseringen af konflikten på vej, kom under kraftig beskydning, og vestlige regeringer og internationale institutioner stimlede nu sammen i forsvar for den danske regering. Hvordan kan denne pludselige udvikling forklares?

Kort efter at imam-delegationerne vendte tilbage til Danmark i december 2005, begyndte de første store demonstrationer mod Muhammedkarikaturerne i Mellemøsten, og i midten af januar 2006 spredtes boykotten af danske produkter hurtigt i regionen. Eskaleringen af konflikten i udlandet kulminerede med de voldelige angreb mod danske diplomatiske repræsentationer i begyndelsen af februar 2006. Hvorvidt imam-delagationerne startede denne eskalering, er et meget omstridt spørgsmål, som jeg ikke vil diskutere her. Jeg vil blot bemærke, at imam-delegationerne og de motiver, de blev tilskrevet, trådte ind i den danske offentlighed i januar 2006 og blev et centralt emne i den offentlige debat med afgørende betydning for de involverede muslimske aktører. Debatten ændrede karakter i denne fase af krisen, hvilket afspejles i de emner, der blev fokuseret på i kravfremsættelsen.Tabel 1 viser de vigtigste emner for krav fra både muslimske og ikke-muslimske aktører igennem krisens forskellige faser. Et emne defineres som det diskussionstema, hvorom en specifik påstand fremsætter krav.

Tabel 1. Emner for alle (muslimske og ikke-muslimske) krav fordelt på faser ${ }^{\mathrm{a}} \mathrm{i}$ krisen $^{\mathrm{b}}$

\begin{tabular}{|l|ll|ll|ll|ll|ll|}
\hline \hline & \multicolumn{2}{|l|}{ Fase 1 } & \multicolumn{2}{|l|}{ Fase 2 } & \multicolumn{2}{|l|}{ Fase 3 } & \multicolumn{2}{|l|}{ Fase 4 } & \multicolumn{2}{|l|}{ Totalt } \\
& $\mathrm{N}$ & $\%$ & $\mathrm{~N}$ & $\%$ & $\mathrm{~N}$ & $\%$ & $\mathrm{~N}$ & $\%$ & $\mathrm{~N}$ & $\%$ \\
\hline Muslimsk håndtering af konflikten & 10 & 7.1 & 62 & 29.1 & 40 & 13.5 & 15 & 8.8 & 127 & 15.5 \\
Ytringsfrihed & 26 & 18.6 & 18 & 8.5 & 42 & 14.1 & 30 & 17.6 & 116 & 14.1 \\
Regeringens håndtering af konflikten & 25 & 17.9 & 25 & 11.7 & 23 & 7.7 & 30 & 17.6 & 103 & 12.6 \\
Konfliktløsning & 13 & 9.3 & 41 & 19.2 & 32 & 10.8 & 15 & 8.8 & 101 & 12.3 \\
Diskrimination & 23 & 16.4 & 13 & 6.1 & 18 & 6.1 & 11 & 6.5 & 65 & 7.9 \\
Integration & 1 & 0.7 & 9 & 4.2 & 26 & 8.8 & 22 & 12.9 & 58 & 7.1 \\
Vold & 11 & 7.9 & 5 & 2.3 & 31 & 10.4 & 10 & 5.9 & 57 & 7.0 \\
Tolerance/Respekt & 14 & 10.0 & 8 & 3.8 & 22 & 7.4 & 6 & 3.5 & 50 & 6.1
\end{tabular}




\begin{tabular}{|l|ll|ll|ll|ll|ll|} 
Islam som religion & 4 & 2.9 & 9 & 4.2 & 10 & 3.4 & 14 & 8.2 & 37 & 4.5 \\
Mediernes adfærd & 6 & 4.3 & 11 & 5.2 & 15 & 5.1 & 2 & 1.2 & 34 & 4.1 \\
Lighed/ligestilling & 4 & 2.9 & 7 & 3.3 & 9 & 3.0 & 7 & 4.1 & 27 & 3.3 \\
Globalisering & 0 & 0.0 & 1 & 0.5 & 13 & 4.4 & 5 & 2.9 & 19 & 2.3 \\
Andre emner & 3 & 2.1 & 4 & 1.9 & 16 & 5.4 & 3 & 1.8 & 26 & 3.2 \\
\hline Totalt & 140 & 17.1 & 213 & 26.0 & 297 & 36.2 & 170 & 20.7 & 820 & 100 \\
\hline \hline
\end{tabular}

a. Fase 1: 30. september 2005 til 25. december 2005; fase 2: 26. december 2005 til 3.

februar 2006; fase 3: 4. februar 2006 til 25. februar 2006; fase 4: 26. februar 2006 til 20. marts 2006.

b. Procenttallet i hver celle viser procentdelen af et specifikt emne i forhold til alle emner rejst $\mathrm{i}$ en given fase

Tabellen viser, at emner som diskrimination, ytringsfrihed og regeringens håndtering af konflikten (for eksempel afslaget på at mødes med muslimske ambassadører) dominerede den første fase af krisen, mens emner angående legitimiteten af den muslimske håndtering af konflikten - først og fremmest anvendelsen af transnational aktivisme - dominerede i krisens anden fase. Næsten $30 \%$ af alle fremsatte krav i anden fase berørte dette emne.

Flere aspekter af imam-delegationerne blev gransket af offentligheden i krisens anden fase. Blandt disse var indholdet af den sagsmappe, som imamerne havde taget med sig til Egypten, Libanon og Syrien. Foruden de tolv Muhammedkarikaturer og arabiske oversættelser af de artikler, der ledsagede dem i Jyllands-Posten, indeholdt mappen kopier af breve, som koalitionen havde sendt til politikere, brevet fra de muslimske ambassadører til den danske statsminister, Statsministerens svar samt et antal hånende billeder, som ikke var blevet publiceret, men sendt til danske muslimer som privat 'hade-post'. Mange kritikere mente, at det kunne være svært at afgøre, hvad der var blevet offentliggjort bredt, og hvad der ikke var, alene ved at se på indholdet af mappen. Det blev ligeledes pointeret, at den arabiske oversættelse af danske navne på muslimske organisationer, som var involveret i protestkoalitionen, overdrev omfanget af støtten. For eksempel blev 'dansk' til 'skandinavisk' i et navn (Nielsen 2006). 
Særligt ét bestemt billede i sagsmappen blev diskuteret i stor udstrækning. Billedet viser en mand med griseører og tryne med følgende billedtekst: "Her er jeres Profet Muhammed". En af de danske imamer fra delegationen, Abu Bashar, viste i en nyhedsudsendelse på BBC tegningen til Generalsekretæren for Den Islamiske Konference-Organisation, Ekmeleddin Ihsanoglu. Mange i Danmark kunne ikke se, hvordan dette billede, som var sendt til en dansk muslim i en privat mail, var relevant for debatten om Muhammedkarikaturerne. Det blev desuden bemærket, at artikler, som indeholdt misforståelser om situationen i Danmark, ofte blev bragt i den arabiske presse samtidig med de danske imamers besøg. Det blev eksempelvis påstået, at Dansk Folkeparti var en del af den danske regering og at danske muslimer ikke havde lov til at bygge moskeer. En dansk forsker, som overvågede den arabiske presse, udtalte følgende:

Det er påfaldende at hver gang et besøg fra delegationen nævnes, indeholder artiklen meget forkerte informationer om situationen i Danmark. Jeg er nødt til at sige, at det er et meget mistænkeligt sammentræf (Ziadeh 2006).

Ud fra disse observationer om timingen af delegationerne og den efterfølgende eskalering af konflikten i Mellemøsten konkluderede flere personer i den danske debat, heriblandt dele af den politiske elite, at imamerne havde været med til at smide brænde på bålet i udlandet. Den daværende danske Socialminister, Karen Jespersen (V), formulerede det således:

Imamerne hældte benzin på denne stemning ved at kolportere et rygte om, at danske racister havde planer om at afbrænde Koranen. Således gav de deres bidrag til den tiltagende ophidselse, der endte med boykot, massedemonstrationer, afbrænding af Dannebrog og billeder af statsministeren samt med angreb på danske diplomatiske repræsentationer (Jespersen \& Pittelkow 2006: 27).

Argumenter om 'loyalitet' og 'sikkerhed' blev således centrale. Sagt på en anden måde blev imamdelegationerne 'sikkerhedsliggjort' ved deres indtræden i den danske offentlige debat (Buzan, Wæver \& de Wilde 1998). Idet sagen blev gjort til et nationalt sikkerhedsspørgsmål, lagde det op til ekstraordinær politisk opmærksomhed og handling. Ud fra dette perspektiv havde imam-delegationerne 
sat den nationale sikkerhed på spil ved at kanalisere vreden fra muslimske regimer og ekstremister mod Danmark. Som følge heraf blev de involverede danske muslimer beskrevet som eksempelvis 'fjenden indefra' eller ganske enkelt 'forrædere'. Denne tankegang blev sat på spidsen, da Dansk Folkeparti opfordrede til en undersøgelse af muligheden for at tilbagekalde statsborgerskabet for fire navngjorte imamer, som havde deltaget i delegationerne, på grundlag af landsforræderi. Sådanne ekstraordinære tiltag resonerede fint med opfattelsen af 'undtagelsestilstand' blandt store dele af den danske befolkning og den politiske elite: Danmark stod over for den værste udenrigspolitiske krise siden anden verdenskrig. Sikkerhedsliggørelsen af danske muslimers transnationale aktiviteter skabte således en diskursiv mulighed for politiske autoriteter, som åbnede op for repression af de involverede muslimske aktører. Det var ikke kun den yderste højrefløj, som greb muligheden for at stigmatisere og fremmedgøre de centrale aktører fra den muslimske protestkoalition bag imam-delegationerne. Den politiske elites delegitimering var næsten komplet, som eksempelvis da integrationsminister Rikke Hvilshøj (V) foreslog, at regeringen stoppede med at involvere danske imamer i integrationsprojekter. Forslaget om at stoppe samarbejdet med muslimske religiøse autoriteter vandt bred støtte på tværs af det politiske spektrum i februar 2006. Dette afspejlede opfattelsen af, at de involverede aktører ikke havde taget den nødvendige afstand fra gamle loyaliteter, normer, identiteter og forbindelser til at kunne fungere som tillidsfulde partnere i arbejdet for muslimsk integration i Danmark.

Tabel 2. Andel af krav fremsat af forskellige muslimske organisationer fordelt på faser ${ }^{\mathrm{a}} \mathrm{i}$ krisen ${ }^{\mathrm{b}}$

\begin{tabular}{|l|ll|ll|ll|ll|l|l|}
\hline \hline \multirow{2}{*}{ Muslimske Organisationer } & \multicolumn{2}{|l|}{ Fase 1 } & \multicolumn{2}{|l|}{ Fase 2 } & \multicolumn{2}{|l|}{ Fase 3 } & \multicolumn{2}{|l|}{ Fase 4 } & \multicolumn{2}{|l|}{ Totalt } \\
& $\mathrm{N}$ & $\%$ & $\mathrm{~N}$ & $\%$ & $\mathrm{~N}$ & $\%$ & $\mathrm{~N}$ & $\%$ & $\mathrm{~N}$ & $\%$ \\
\hline Islamisk Trossamfund & 14 & 22.6 & 42 & 39.6 & 16 & 14.4 & 13 & 19.7 & 85 & 24.6 \\
Muslimer i Dialog & 6 & 9.7 & 16 & 15.1 & 30 & 27.0 & 10 & 15.2 & 62 & 18.0 \\
Demokratiske Muslimer & 2 & 3.2 & 14 & 13.2 & 19 & 17.1 & 18 & 27.3 & 53 & 15.4 \\
Muslimsk Protestkoalition & 23 & 37.1 & 15 & 14.2 & 1 & 0.9 & 12 & 18.2 & 51 & 14.8 \\
Hizb ut-Tahrir & 3 & 4.8 & 6 & 5.7 & 17 & 15.3 & 7 & 10.6 & 33 & 9.6 \\
Kritiske Muslimer & 1 & 1.6 & 1 & 0.9 & 10 & 9.0 & 4 & 6.1 & 16 & 4.5 \\
The Network & 0 & 0.0 & 2 & 1.9 & 9 & 8.1 & 2 & 3.0 & 13 & 3.8 \\
Andre & 13 & 21.0 & 10 & 9.4 & 9 & 8.1 & 0 & 0.0 & 32 & 9.3 \\
\hline Totalt & 62 & 18.0 & 106 & 30.7 & 111 & 32.2 & 66 & 19.1 & 345 & 100 \\
\hline \hline
\end{tabular}


a. Fase 1: 30. september 2005 til 25. december 2005; fase 2: 26. december 2005 til 3. februar 2006; fase 3: 4. februar 2006 til 25. februar 2006; fase 4: 26. februar 2006 til 20. marts 2006 .

b. Procenttallet i hver celle viser procentdelen af krav fra en specifik muslimsk organisation i forhold til det totale antal krav fremsat i en given fase.

Den massive kritik og bløde repression, særligt af Islamisk Trossamfund, ledet af imam Ahmed Abu Laban, og protestkoalitionen, repræsenteret af den unge imam Ahmed Akkari, havde alvorlige konsekvenser for disse aktørers senere kravfremsættelse i debatten. Tabel 2 viser andelen af de samlede muslimske kravfremsættelser for de centrale muslimske aktører i den offentlige debat gennem karikaturkrisens faser. Tabellen viser, at andelen af krav fra den muslimske protestkoalition faldt med mere end $50 \%$ fra fase et til fase to i krisen. Efter den voldelige eskalering af konflikten i udlandet ved begyndelsen af fase tre forsvandt protestkoalitionen næsten helt som kravfremsætter i den offentlige debat - fra 14,2 \% af alle muslimske kravfremsættelser til blot 0,9\% i tredje fase. Islamisk Trossamfund, som havde meget på spil i protestkoalitionen, og som samarbejdede tæt med koalitionens ledere, så ud til at føre an i kravfremsættelsen i krisens anden fase. Efter de voldelige angreb i udlandet var Islamisk Trossamfund dog også tvunget til at indtage en mere defensiv rolle, og deres andel af de muslimske kravfremsættelser faldt fra omkring 40 til under $15 \%$. Tilbagetrækningen fra de to dominerende aktører i de indledende protester mod Muhammedkarikaturerne på netop dette tidspunkt skal ses som en konsekvens af deres rolle, virkelig eller ej, i forbindelse med konfliktens eskalering $\mathrm{i}$ udlandet gennem de transnationale aktiviteter. De dominerende aktører fra den første bølge af protester blev mødt med hård kritik, stigmatisering og deligitimering og anså derfor deres chancer for en fortsat succesfuld kravfremsættelse for at være reducerede. Tilbagetrækningen fra de aktører, som havde bidraget til imam-delegationerne, banede vejen for nye muslimske aktører i den offentlige debat, som kunne udnytte situationen ved at positionere sig selv i opposition til de muslimske aktører fra den første protestbølge. Som følge af kritikken af imam-delegationerne vandt aktører som Muslimer i Dialog, Kritiske Muslimer, The Network og i særdeleshed det nyoprettede Demokratiske Muslimer momentum i debattens anden og tredje fase. Demokratiske Muslimer blev lanceret som et 'alternativ' til de 'radikale' imamer. Naser Khader, som var initiativtager til organisationen, sagde for eksempel følgende: 
Hvad der er brug for er en organisation, som protesterer imod religiøs indkredsning af unge af fundamentale imamer, og sikrer at moderate muslimer bliver hørt i den offentlige debat om islam. Muslimer som er imod dødsstraf og shari'a, og som går ind for religion som en privatsag. (Arpi \& Brøndum 2006).

Handlingerne og kravene fra de dominerende aktører i den første protestrunde blev således stemplet som 'radikale' af både ikke-muslimske kommentatorer/autoriteter og muslimske organisationer. Mens disse 'radikale' aktører blev ekskluderet gennem blød repression, blev nye 'moderate' muslimske aktører på scenen, specielt Demokratiske Muslimer, anerkendt og inkluderet af danske myndigheder. Dette skete gennem et meget symbolsk møde mellem Demokratiske Muslimer og Statsminister Anders Fogh Rasmussen (V) den 13. februar 2006. Denne anerkendelse/miskendelse af forskellige muslimske aktører på dette tidspunkt i krisen kan fortolkes som et eksempel på, hvad der inden for social bevægelsesteori kaldes 'the radical flank effect'. Logikken bag den mekanisme er, at protestaktioner, som opfattes som radikale og/eller illegitime af nogle aktører, fører til modmobilisering blandt mere moderate stemmer, og at flere ressourcer allokeres til denne nye flanke (oprindeligt Herbert 1984). Med andre ord blev magtbalancen og mulighederne for at fremsætte krav blandt forskellige muslimske aktører forskubbet af de repressive tiltag, der blev iværksat som respons på imam-delegationerne.

Den omfattende offentlige kritik af de danske muslimers transnationale aktiviteter i den anden og tredje fase i krisen påvirkede ikke kun det relative niveau af kravfremsættelser blandt muslimske aktører. Som vist i tabel 1 forandrede det de generelle vilkår for debatten. Danske muslimer havde forud for imam-delegationerne og den efterfølgende eskalering af konflikten i udlandet lagt vægt på, at de var ofre for et uprovokeret angreb og havde krav på en form for symbolsk erstatning. Det blev dog vanskeligere at opretholde denne argumentation, da krisen bevægede sig ind i sin tredje og fjerde fase. Danske muslimer tilpassede sig denne nye situation ved blandt andet at moderere deres bud på en løsning af konflikten og deres argumentationsform i retning af flere opfordringer til dialog og ikke-vold samt krav om retfærdiggørelse baseret på liberale rettigheder og moralske principper. $^{3}$ 


\section{En negativ boomerang-effekt: Teoretiske udfordringer og implikationer}

Mit empiriske argument kan opsummeres som følger: Den transnationale aktivisme blandt bestemte danske muslimske aktører, specielt imam-delegationerne, blev i den offentlige debat i Danmark opfattet som den udløsende faktor for konfliktens eskalering i Mellemøsten. Således blev de involverede muslimske aktører, særligt medlemmer af protestkoalitionen og Islamisk Trossamfund, anklaget for bevidst at smide brænde på bålet $\mathrm{i}$ udlandet og for illoyalitet eller endda landsforræderi mod Danmark. Denne sikkerhedsliggørelse af den transnationale aktivisme i den offentlige debat gav politiske autoriteter mulighed for at marginalisere centrale aktører gennem blød repression (stigmatisering og offentlig afstandstagen). Denne udvikling fik afgørende betydning for muslimernes videre kravfremsættelse. For det første så vi, hvordan aktørerne bag imam-delegationerne reagerede på den bløde repression, som mødte dem ved at nedtone niveauet af kravfremsættelse i den offentlige sfære, mens andre muslimske aktører blev mere involveret. Disse nye aktører blev belønnet for deres 'moderathed' - for eksempel deres insisteren på religion som en privatsag - gennem legitimerende tilkendegivelser fra politiske autoriteter. For det andet så vi, hvordan de muslimske aktører generelt tilpassede sig den nye situation og fokusskiftet i den offentlige debat ved at moderere deres løsningsforslag og retfærdiggørelse af krav.

Hvis vi vender tilbage til dynamikken mellem repression og mobilisering, og særligt den teoretiske model om 'boomerang-effekten', har dette empiriske argument flere implikationer. Det er for det første påfaldende i sagen om karikaturkrisen, at konsekvenserne af danske muslimers transnationale aktivisme overvejende er negative. I modsætning til muslimernes forventninger og den klassiske boomerang/spiral-model gav det transnationale træk bagslag og vanskeliggjorde, frem for promoverede, de danske muslimers krav om anerkendelse af sårede religiøse følelser. For det andet gav de transnationale aktiviteter bagslag, fordi de blev opfattet og framet af magtfulde aktører i samfundet som aggressive, illoyale og endda forræderiske handlinger. Denne framing af transnationaliseringen åbnede op for blød repression fra både medierne og den politiske elite, hvilket ændrede de politiske mulighedsstrukturer for mobilisering og kravfremsættelse for de involverede muslimske aktører. Den forventede boomerang-effekt blev med andre ord negativ, fordi der skete en succesfuld sikkerhedsliggørelse af det transnationale træk. For det tredje blev sikkerhedsliggørelsen af den transnationale aktivisme og den bløde repression af udvalgte muslimske aktører hjulpet på vej af 
timingen af krisens udvikling og det faktum, at der i den konkrete version af boomerang-modellen var tale om borgere med immigrantbaggrund, som var bosat i et komparativt set velfungerende demokratisk samfund, og som appellerede om hjælp/støtte fra regimer og religiøse autoriteter i samfund med en mindre imponerende historie for demokratisk deltagelse og overholdelse af menneskerettigheder. Det skabte et ramaskrig i den danske offentlighed, at danske muslimer, hvoraf nogle var kommet til Danmark som politiske flygtninge, rakte hånden ud til de selv samme regimer, som de i sin tid var flygtet fra. Det strømmede ind med kommentarer og læserbreve til avisredaktører med beskyldninger om, at de involverede muslimske aktører "ikke udviste taknemlighed" over for den danske stat og om opfordringer om at "tage tilbage hvor de kommer fra", hvis det er der, deres “sympatier virkelig ligger”. Flere påpegede ligeledes det åbenbare paradoks: Danske muslimer brugte aktivt deres ytringsfrihed til at protestere imod publiceringen af karikaturerne ved at involvere aktører, som ønskede at begrænse ytringsfriheden. Disse omstændigheder bevirkede, at den tilsigtede boomerang-effekt af imam-delegationerne ikke var i overensstemmelse med den offentlige opinions opfattelse af, hvad der var acceptabel politisk aktivisme.

Studiet af danske muslimers transnationale aktiviteter under karikaturkrisen peger på nogle modifikationer af boomerang-modellen for transnational aktivisme. For det første er involvering i transnational aktivisme og boomerang-modellen ikke kun, som det ofte indikeres i litteraturen, en reaktion på hård repression i autoritære regimer, men kan også være en respons på forskellige former for blød repression, som praktiseres i mere demokratiske regimer. For det andet vil en succesfuld sikkerhedsliggørelse af transnational aktivisme i kontekst A (det oprindelige land hvori der blev fremsat krav) betyde, at den forventede boomerang-effekt formentlig får en negativ indflydelse på kravstillernes sandsynlighed for at opnå deres mål. Dette bliver for det tredje særlig sandsynligt, når logikken bag boomerang-modellen ændres således, at kontekst B (landet, som er genstand for den transnationale aktivisme) opfattes som mindre demokratisk end kontekst A. Jeg foreslår derfor nogle begrænsninger i anvendelsesområdet for boomerang-modellen for transnational aktivisme. Modellen vil kun virke efter hensigten, når transnationaliseringen ikke sikkerhedsliggøres og ikke indebærer, at der søges støtte fra regimer, som opfattes som mindre demokratiske end landet, hvori kravene oprindeligt blev fremsat. Det skal imidlertid tilføjes, at flere af casestudierne i Keck og Sikkink's bog antyder, at boomerang-effekten afhænger af legitimiteten hos de aktører, som er involveret i 
transnationale aktiviteter såvel som legitimiteten af deres målgruppe. Disse begrænsninger forbliver dog underforståede, og det samme gælder antydningen af, at en succesfuld anvendelse af boomerangeffekten ikke er lige tilgængelig for alle aktører i samfundet. For nogle aktører, immigranter i særdeleshed, er boomerang-effekten et risikabelt foretagende, som bør håndteres med forsigtighed for ikke at give bagslag. Således er immigranters muligheder for at opbygge eksterne alliancer mere begrænsede end andre aktørers. Aktører med immigrantbaggrund, som involverer deres 'hjemland' med henblik på at ændre situationen i 'bosættelseslandet', vil sandsynligvis have mindst succes med boomerang-effekten. I en sådan situation vil en kombination af sikkerhedsliggørelse, suverænitetsdiskussion og blød/hård repression være næsten uundgåelig, hvilket medfører en høj risiko for, at transnationaliseringen vil give bagslag. Desuden er muslimer, set i forhold til andre minoriteter i Vesten, sandsynligvis den gruppe af aktører, som har størst risiko for at opleve bagslag ved transnational aktivisme, ikke mindst efter terrorangrebene i New York og Washington den 11. september 2001. På mange måder står muslimske aktører, som deltager i offentlige diskussioner over for exceptionelle normer i forhold til den måde, hvorpå der fremsættes krav. Således synes standarderne for klarhed, tydelig bekræftelse af fælles værdier og tilkendegivelse af loyalitet at være højere for muslimer end andre aktører i den offentlige debat (se også Lindekilde 2012). De, som ikke lever op til disse standarder, er i fare for at blive overhørt eller bandlyst. I denne optik står muslimske talspersoner over for en exceptionelt høj risiko for at blive udsat for blød repression, og når dette får muslimske aktører til at forfølge deres krav gennem transnational aktivisme, vil det med stor sikkerhed give bagslag.

Sagen om danske muslimers transnationale aktivisme under karikaturkrisen er en god påmindelse om ikke at overvurdere det positive potentiale ved transnational aktivisme, men at tage de forskellige omstændigheder med i betragtning. Dette synes ikke mindst vigtigt i en tid, hvor der kan være en tendens til at forherlige og overdrive betydningen af internetbaseret transnational aktivisme i det 'arabiske forår' (Lunch 2011: 304). Der kan stilles spørgsmål ved legitimiteten af at lægge pres på en stat eller statslige aktører gennem transnational aktivisme for at opnå politiske indrømmelser, og dette kan vendes imod de transnationale aktivister. Indtil videre har der i litteraturen været for lidt fokus på risikoen og potentielle ulemper ved at deltage i (internetbaseret) transnational aktivisme (Morozov 2011). Dette gælder i særdeleshed for aktører med muslimsk baggrund. Megen forskning om 
transnational aktivisme tager for givet, at stigningen i niveauet af transnational aktivisme, som følge af spredningen af transnationale kommunikationsværktøjer og større mobilitet, også vil skabe en stigning i mængden af succesfulde transnationale kampagner. Studiet af den negative boomerang-effekt i den her diskuterede case peger imidlertid på nogle begrænsninger i denne tendens. Den foregående analyse understreger yderligere vigtigheden af blød repression for mobilisering/demobilisering, både direkte (i forhold til valg af handling) og indirekte gennem bagslagsmekanismer (konsekvenserne af handlingen). Denne viden kan tjene som en advarsel mod den gængse antagelse om, at repression er sjælden i demokratiske samfund (selvom hård repression ofte er det), mens det er en del af hverdagen i autoritære regimer.

\section{Positive konsekvenser på lang sigt?}

Danske muslimers aktivering af boomerang-effekten under karikaturkrisen i 2005-06 viste sig at have negative konsekvenser for opnåelsen af de danske muslimers krav om en form for symbolsk anerkendelse. Der kan dog være tale om mere positive langsigtede konsekvenser - særligt for nogle danske muslimer. For at sætte resultaterne fra den empiriske analyse og den teoretiske diskussion ovenfor i perspektiv, vil jeg kort undersøge de mere langsigtede konsekvenser af danske muslimers transnationale aktivisme under karikaturkrisen for både danske muslimer og den danske politiske elite. Jeg vil gøre dette ved at diskutere, hvad der er sket i de fem år siden krisen ebbede ud i marts-april 2006. Jeg vil nærmere bestemt se på, hvad der skete i februar 2008 i forbindelse med genoptrykningen af Muhammedkarikaturerne i flere danske aviser som respons på afsløringen af konkrete planer om at slå Muhammed-tegneren, Kurt Westergaard, ihjel.

En undersøgelse af hvordan genoptrykningen af Muhammedkarikaturerne i februar 2008 blev håndteret i Danmark, vidner om en gensidig læringsproces. De danske muslimske aktører bag imamdelegationerne i 2005-06 afholdt sig denne gang fra at spille det transnationale kort, men forsøgte tværtimod bevidst at inddæmme konflikten til en dansk kontekst. Man kan argumentere for, at de er blevet 'socialiseret' gennem den første konflikt til en bedre forståelse af risikoen for bagslag ved en transnational eskalering. Ved et tilbageblik på hvad der kunne være gjort anderledes under krisen i 2005-06, udtalte Ahmed Akkari følgende: 
Hvis vi havde forudset, at vores besøg til Mellemøsten ville blive vendt imod os politisk, og at det flyttede debatten væk fra dens egentlige fokus, ville vi nok have genovervejet at tage af sted og hvem vi ville besøge (Interview med Akkari 27. december 2006).

Ved udsigten til en genoptrykning af karikaturerne forudså de involverede aktører, at transnational aktivisme var dømt til at give bagslag endnu en gang. Desuden var hovedårsagen til overhovedet at deltage i transnational aktivisme - lukkede nationale mulighedsstrukturer - mindre udtalt denne gang, eftersom den danske regering viste sig mere lydhør over for muslimske indsigelser. I kølvandet på genoptrykningen af karikaturerne gik integrationsministeren, Birthe Rønn Hornbech (V), med til at mødes med Det Islamisk Trossamfund for at diskutere situationen og til et officielt besøg i moskéen på Dortheavej. Det er denne form for symbolsk anerkendelse, som var fraværende i den danske regerings håndtering af krisen i 2005-06. Hvorvidt denne nye imødekommenhed overfor muslimske krav skal opfattes som et oprigtigt eller strategisk træk for at undgå en eskalering af konflikten, er svært at sige. Reaktionerne på genoptrykningen af Muhammedkarikaturerne i februar 2008 indikerer, at der er sket en vis socialisering og gensidig tilpasning som følge af konflikten i 2005-06, uanset de bagvedliggende intentioner.

Den empiriske analyse viser, hvordan imam-delegationerne og deres eskalerende konsekvenser blev sikkerhedsliggjort, og hvordan denne fremstilling af begivenhederne åbnede op for (blød) repression. De aktører, som deltog i imam-delegationerne, blev sidenhen presset i baggrunden, mens andre muslimske aktører indtog deres plads i den offentlige debat. På denne måde igangsatte debatten om Muhammedkarikaturerne en rekonfigurationsproces af den offentlige repræsentation af danske muslimer, som ser ud til at være fortsat i de fem år, der er gået siden den første publicering af karikaturerne. Genoptrykningen af karikaturerne i 2008 kan igen tjene som eksempel. Som i 2005-06 var Det Islamisk Trossamfund den stærkeste modstander af genoptrykningen af Muhammedkarikaturerne. Men i modsætning til den oprindelige krise satte andre muslimske organisationer med det samme spørgsmålstegn ved, og tog afstand fra, protesterne fra Det Islamisk Trossamfund. Mest bemærkelsesværdige var kommentarerne fra nogle af de store tyrkiske muslimske organisationer, for eksempel De Tyrkiske Muslimers Trossamfund i København og Sammenslutningen af Muslimske Indvandrer Foreninger, to organisationer, som havde holdt forholdsvis lav profil i 
tidligere offentlige debatter om islam i Danmark, heriblandt 2005-06 krisen. Talsmand Erfan Kurtulos udtalte:

Vi har fælles religion, men de repræsenterer ikke os, og vi tager skarpt afstand fra fanatisme, og den måde imamerne fra Islamisk Trossamfund deltager i samfundsdebatten på. Fanatikerne kan ikke tage patent på islam og integrationsarbejdet i Danmark (Lumby 2008).

Endvidere er Islamisk Trossamfunds status som repræsentant for 'danske muslimer' blevet udfordret af to nye muslimske paraplyorganisationer, som blev etableret efter karikaturkrisen i 2005-06 som et forsøg på at forene hovedparten af de danske muslimer og give dem en fælles stemme. Det drejer sig om Muslimernes Fællesråd, et initiativ iværksat af Muslimer i Dialog med mere end 40.000 medlemmer, og Dansk Muslimsk Union, et initiativ med baggrund i Sammenslutningen af Muslimske Indvandrer Foreninger. Det ser ud til, at fiaskoen med at forene danske muslimer under karikaturkrisen har skabt fornyet interesse for at bygge en fælles organisatorisk platform, som kan fungere som centrum for fremsættelse af krav i fremtidige debatter.

Sammenfattende forhindrede danske muslimers transnationale aktivisme i 2005-06 de umiddelbare chancer for at opnå anerkendelse af muslimske indsigelser. Dette gjorde sig gældende for alle danske muslimer, som delte dette mål, men i særdeleshed for de muslimske aktører, som deltog i imamdelegationerne. For Det Islamisk Trossamfund og andre organisationer, som var involveret $\mathrm{i}$ protestkoalitionen, synes de langsigtede konsekvenser af at have spillet det transnationale kort at være negative. Det Islamisk Trossamfunds position som den ledende repræsentant for danske muslimer er blevet alvorligt udfordret. Denne tendens blev kun forstærket af imam Ahmed Abu Labans død i februar 2007. Set fra andre muslimske organisationers synspunkt, både nyoprettede organisationer og organisationer, som tidligere havde holdt lav profil, fremstår udviklingen mere positivt, fordi deres råderum, støtte og således også villighed til at engagere sig i den offentlige debat er steget. De, som var kritiske over for den danske regerings håndtering af krisen i 2005-06 kan finde trøst i den kendsgerning, at den danske regering tilsyneladende har lært, hvor vigtig og effektiv symbolsk anerkendelse kan være som instrument til konflikthåndtering. Der er således håb for, at danske 
muslimer ikke vil blive mødt med hermetisk lukkede politiske mulighedsstrukturer i fremtidige kriser. Sagt på en anden måde ser det ud til, at danske myndigheder har lært, at selv blød repression kan give bagslag og føre til en eskalering af konflikten. Endeligt anser mange muslimer og ikke-muslimer i Danmark en mere pluralistisk offentlig repræsentation af danske muslimer som en positiv udvikling. Den transnationale aktivisme under karikaturkrisen i 2005-06 og den efterfølgende offentlige debat var, ud fra dette perspektiv, en velkommen mulighed for at bryde udvalgte muslimske aktørers 'monopol' på offentlig repræsentation. 'Sekulære muslimer’ har opnået offentlig momentum i Danmark i de fem år, der er gået siden den første publicering af Muhammedkarikaturerne. Den relative magtbalance blandt muslimske aktører, som forsøger at fremme forskellige forståelser af islam, synes at have skiftet, i det mindste i den offentlige debat, til fordel for aktører, som ubetinget tilslutter sig integration som deres målsætning og proaktivt tilslutter sig værdier som ytringsfrihed, demokrati og ligestilling. Men denne udvikling har også betydet en marginalisering af mere ortodokse miljøer, som af frygt for stemplet 'radikal' i stigende grad afholder sig fra at deltage i den offentlige debat.

Om de arabiske 'onlinerevolutioner' på længere sigt også fører til egentlige regimeforandringer i lande som Tunesien, Algeriet og Egypten, kan kun fremtiden vise. Men, som denne artikel har antydet, så er der behov for at studere de dynamiske relationer mellem forskellige former for transnational aktivisme og repression nærmere i et forsøg på bedre at kunne kortlægge under hvilke omstændigheder transnational politisk aktivisme virker efter hensigten, og hvornår den ikke gør.

\section{Referencer}

Akkari interview, Personligt interview med Ahmed Akkari gennemført d. 27. december 2006.

Arpi, Susanna \& Christian Brøndum, 2006: "Ny forening vil mobilisere det tavse mindretal", Berlingske Tidende, 3. februar, s. 6.

Basch, Linda, Nina Glick Schiller \& Cristina Szanton Blanc, 1994: Nations Unbound: Transnational Projects, Postcolonial Predicament and Deterritorialized Nation-states Gordon \& Breach Science Publishers S.A., Basal.

Buzan, Barry, Ole Wæver \& Jaap de Wilde, 1998: Security: A New Framework for Analysis, Lynne Rienner, Boulder. 
Danese, Gaia, 1998: "Transnational Collective Action in Europe: The Case of Immigrants in Italy and Spain”, in: Journal of Ethnic and Migration Studies, nr. 24: 715-33.

della Porta, Donatella \& Sidney Tarrow, 2004: Transnational Protest and Global Activism, Rowman \& Littlefield, Lanham.

Ferree, Myra Marx, 2005: “Soft Repression: Ridicule, Stigma and Silencing in Gender-Based Movements", in: Christian Davenport, Hank Johnston, \& Carol Mueller (eds.): Repression and Mobilization, University of Minnesota Press, Minneapolis. Pp. 138-155.

Guarnizo, Luis Edourdo \& Alejandro Portes, 2003: “Assimilation and Transnationalism: Determinants of Transnational Political Action among Contemporary Immigrants”, in: American Journal of Sociology, nr. 108: 1211-248.

Guiraudon, Virginie, 2001: "Weak Weapons of the Weak? Transnational Mobilization around Migration in the European Union", in Doug Imig \& Sidney Tarrow (eds.): Contentious EuropeansProtest and Politics in an Emerging Polity, Rowman \& Littlefield: Boston. Pp. 163-183.

Herbert, Haines, 1984: "Black Radicalization and the Funding of Civil Rights: 1957-1970”, in Social Problems nr. 32: 31-43.

Hess, David \& Brian Martin: "Repression, Backfire and the Theory of Transformative Events", in Mobilization: The International Journal of Research on Social Movements, Protest and Collective Behavior Mobilization, nr. 11:249-67.

Islamisk Trossamfund, 2. marts 2006: Hvorfor tegningerne? Hvorfor Muslimer? Hvorfor al-Azhar?, internt nyhedsbrev fra Islamisk Trossamfund, http://www.wakf.com (hentet 3. marts 2006).

Jespersen, Karen og Ralf Pittelkow, 2006: Islamister og naivister, People’s Press: København. 
Johnston, Hank, 2005: “Talking the Walk: Speech Acts and Resistance in Authoritarian Regimes", in: Christian Davenport, Hank Johnston, \& Carol Mueller (eds.): Repression and Mobilization, University of Minnesota Press, Minneapolis. Pp. 108-137.

Keck, Margaret E. \& Kathryn Sikkink, 1998: Activists beyond Borders: Advocacy Networks in International Politics, Cornell University Press: Ithaca, N.Y.

Koopmans, Ruud, 2005: "Repression and the Public Sphere: Discursive Opportunities for Repression against the Extreme Right in Germany in the 1990s", in: Christian Davenport, Hank Johnston, \& Carol Mueller (eds.): Repression and Mobilization, University of Minnesota Press, Minneapolis. Pp. 159-189.

Koopmans, Ruud \& Paul Statham, 1999a: "Political Claims Analysis: Integrating Protest Event and Political Discourse Approaches", in: Mobilization: The International Journal of Research on Social Movements, Protest and Collective Behavior, nr. 4: 597-626.

- 1999b: "Challenging the Liberal Nation-State? Postnationalism, Multiculturalism and the Collective Claims-Making of Immigrants and Ethnic Minorities in Britain and Germany", in: American Journal of Sociology, nr. 105: 652-96.

Lichbach, Mark, 1987: “Deterrence or Escalation? The Puzzle of Aggregate Studies of Repression and Dissent", in Journal of Conflict Resolution, nr. 31: 266-97.

Lindekilde, Lasse, 2012: "Radicalization Prevention and Potential Iatrogenic Effects. The Case of Danish Radicalization Prevention Policies", forthcoming in: International Journal of Conflict and Violence, nr. 6, april/maj 2012.

- 2010: "Soft Repression and Mobilization: The Case of Transnational Activism of Danish Muslims During the Cartoons Controversy", in: International Journal of Middle East Studies, nr. 42: 451-469. 
Lumby, Elisabeth, 2008: "Muslimer i oprør over Islamisk Trossamfund”, Berlingske Tidende, 21. februar, s. 3.

Lunch, Marc, 2011: "After Egypt: The Limits and Promises of Online challenges to the Authoritarian Arab State", in: Perspectives on Politics, nr. 9: 301-310.

Morozov, Evgeny, 2011: The Net Delusion: The Dark Side of Internet Freedom, Public Affairs: New York.

Muslimer i Dialog, 9. februar 2006: Muslimer vil skabe forsoning, hjemmesiden for Muslimer i Dialog, http://www.m-i-d.dk/ (hentet 9. februar 2006).

Nielsen, Helle Lykke, 2006: "Rejsen”, in: Information om Indvandrere, nr. 14: 4-11.

Olesen, Thomas, 2007: “The Porous Public and the Transnational Dialectic: The Muhammed Cartoons Conflict", in: Acta Sociologica, nr. 50: 295-308.

- 2005: "Transnational Publics: New Spaces of Social Movement Activism and the Problem of Global Long-Sightedness", in: Current Sociology, nr. 53 419-40.

Portes, Alejandro, 1997: Globalization from Below: The Rise of Transnational Communities, Princeton University Working Papers, Princeton, N.J.

Schiffauer, Werner, 2008: "Suspect Subjects: Muslim Migrants and the Security Agencies in Germany”, in: Julia M. Eckert (ed.): The Social Life of Anti-Terrorism Laws, Transcript Verlag: Bielefeld. Pp. 55-79.

Shirky, Clay, 2011: “The Political Power of Social Media”, in: Foreign Affairs, nr. 90: 28-41. 
Strawn, Kelley D, 2008: "Validity and Media-derived Protest Event Data: Examining Relative Coverage Tendencies in Mexican News Data", in: Mobilization: The International Journal of Research on Social Movements, Protest and Collective Behavior, nr. 13: 147-64.

Tarrow, Sidney \& Charles Tilly, 2006: Contentious Politics, Paradigm Publishers: Boulder.

Van Hear, Nicholas, 1998: New Diasporas, UCL Press Limited: London.

White, Robert, 1993: “On Measuring Political Violence: Northern Ireland 1969-1980”, in: American Sociological Review, nr. 58: 575-85.

Ziadeh, Hanna, 2006: "Danske muslimer beskyldes for arabisk smædekampagne”, in: Berlingske Tidende, 17. januar, s. 4.

\section{Om forfatteren}

Lasse Lindekilde, er siden 2009 ansat som adjunkt ved Institut for Statskundskab, Aarhus Universitet. Han er ph.d. fra Det Europæiske Universitets Institut i Firenze på en afhandling om danske muslimers reaktioner på publiceringen af Muhammed-karikaturerne (2008). Hans primære forskningsinteresser er religiøs aktivisme, teorier om sociale bevægelser og integrationspolitik. Senest har han forsket i radikaliseringsprocesser, forebyggelse af radikalisering og spørgsmål om tolerance og tolerancens grænser i forhold til minoriteters politiske deltagelse. Han har publiceret adskillige international tidsskriftsartikler og bogkapitler om disse emner, heriblandt; "Neo-liberal Governing of 'Radicals': Danish Radicalization Prevention Policies and Potential iatrogenic Effects", under udgivelse i International Journal of Conflict and Violence, maj 2012. "Radicalization and the Limits of Tolerance", under udgivelse i Journal of Ethnic and Migration Studies, april 2012, sammen med Lene Kühle. "Soft Repression and Mobilization: The case of Transnational Activism of Danish Muslims during the Cartoons Controversy", International Journal of Middle East Studies, 42(3). 2010. "Muslim Claims-making in Context: Comparing the Danish and the Swedish Muhammad Caricatures Controversies”, Ethnicities, 9(3), 2009, sammen med Göran Larsson, Göteborg Universitet. 


\title{
http://pure.au.dk/portal/da/persons/lasse-lindekilde(c3a91343-f2ea-4695-8dc2-47bccf1d0887).html
}

\begin{abstract}
${ }^{1}$ Analysen i denne artikel opdeler krisen i fire faser. Denne opdeling bygger på anvendelsen af to kriterier for afgrænsning 1) omfanget af konflikten og 2) intensiteten af konflikten. Groft sagt er første fase (30. september-25. december 2005) karakteriseret ved et lokalt/nationalt omfang og et relativt lavt intensitetsniveau, anden fase (26. december 2005-3. februar 2006) ved et internationalt omfang og et middel intensitetsniveau, tredje fase (4-25. februar 2006) ved et internationalt/globalt omfang og et højt intensitetsniveau og fjerde fase (26. februar-20. marts 2006) er karakteriseret ved et nationalt omfang og lavt til middel intensitetsniveau.

${ }^{2}$ I avislandskabet placerede Berlingske Tidende sig mellem polerne med Jyllands-Posten på den ene side, som insisterede på, at andre værdier/rettigheder var ytringsfriheden underlegne, og Politiken på den anden side, som var den største kritiker af karikaturerne og den danske regerings håndtering af krisen. Berlingske Tidende valgte, af respekt for muslimske følelser, ikke at publicere karikaturerne, men støttede Jyllands-Postens ret til at publicere dem samt regeringens ikkeinterventionsstrategi.

${ }^{3}$ For en detaljeret analyse af forandringerne over tid i indhold af muslimske krav gennem krisen se Lindekilde 2010.
\end{abstract}

